http://dx.doi.org/10.18778/8142-006-8.07

\title{
FROM THE KiTCHEN TO THE WORLD - CHANGES OF WOMEN's STATUS AND ATTITUDES ON THE EXAMPLE OF THE MEXICAN INDIAN VILLAGES IN THE LA HUASTECA HidALGUENSE REGION
}

\section{Zofia PIotrowsKa-KRETKIEWICZ}

Institute of Regional and Global Studies, University of Warsaw

The aim of the paper is to present the changes of the status of the indigenous peasant women in Mexico on the example of the small Huazalingo municipality in the La Huasteca Hidalguense region. The majority of inhabitants of the municipality are Nahua Indians. The paper is based on the results of the multidisciplinary investigations carried out in Huazalingo municipality since December 1999 till the present time, consisting of prolonged periods of fieldwork and numerous sporadic visits. Huazalingo municipality is located on the periphery of the Hidalgo state and the La Huasteca region, therefore, the market access for its agriculture produce is very limited. Changes of economic conditions compelled the Indian peasants to construct some kind of the nomadic community or the nomadic culture - i.e. the existence and the survival of the families and village as a whole was made possible thanks to the periodical or permanent migrations of the younger generation. The agricultural production does not provide sufficient wealth to cover the family expenses or to make investment for the future. At the same time, with the increasing migration rate and the absence of young men in the villages, the status of women has changed, and, accordingly, the tasks they have to fulfil in the community have been modified.

Changes in the women's status that have come about in the traditional Indian villages for the several decades are of both positive and negative nature. On one hand, due to the absence of young men in the villages, women gained more autonomy, better access to education and, consequently, they became more independent. On the other hand, currently, they have to fulfil more extended domestic chores and the emergence of new tasks means that, like in the past, their working hours are much longer than those of men.

La Huasteca is a geographical-historical and socio-cultural region located in the north-eastern part of Mexico. The precise extension and the limits of the region are not defined univocally. In accordance with the broad definition, 
it comprises the eastern part of San Luis Potosi State, the north-eastern part of Hidalgo, the northern part of Veracruz, the south-eastern part of Tamaulipas and the north-eastern part of Puebla. Notwithstanding, it has become commonplace to distinguish three separate regions (or three Huastecas): the Huasteca Hidalguense, Veracruzana, and Potosina. Already in the pre-Columbian era, La Huasteca was considered by the Aztecs to be a mysterious and mythic territory. It is a region of many contrasts. Although it is rich in natural resources and its environment is favourable for agriculture, it represents one of the poorest regions of Mexico. Paradoxically, the area with such an abundance of natural and valuable resources that have many potential usages, is inhabited by millions of indigenous people suffering poverty and endemic underdevelopment. According to the census conducted in 2010 (Censo de Población y Vivienda 2010) the La Huasteca region was inhabited by almost 3.5 million people, $23.6 \%$ of them belonged to one of the indigenous groups (Indians). The most numerous group were the Nahuas (nahuatl speaking group).

La Huasteca hidalguense is a part of La Huasteca that belongs to the Hidalgo state. The region is a hilly terrain that is affected by the soil erosion. It is composed of 10 municipalities. $88 \%$ of its population are Nahua Indians (Panorama Sociodemográfico de Hidalgo 13). The main economic activity of its inhabitants is agriculture. Notwithstanding, their farming activities are characterised by a very low rate of technicality. The main reason for this situation is the mountainous topography, dynamic landforms, steep, stony slopes that make it impossible to use the modern equipment and machines.

The Huazalingo Municipality is located on the periphery of the Hidalgo State and the la Huasteca region. The territorial area of Huazalingo is $107.38 \mathrm{~km}^{2}$ and it represents just $0.52 \%$ of the territory of the State. Its total population is 12,779 inhabitants (i.e. just $0.48 \%$ of the total population of the state). Huazalingo is located at an altitude of approximately $890 \mathrm{~m}$ above the sea level (Anuario Estadistico 2014). According to the official data, Huazalingo belongs to the group of municipalities the most severely affected by poverty in the Hidalgo State. According to the official publications (Anuario Estadístico y Geográfico de Hidalgo 2014), (Medición de Pobreza Municipal 2010), in the period of 2008-2010 and in 2010-2013, Huazalingo was one of the municipalities with the highest social marginalisation rates at the State level.

The population of Huazalingo is very young. The median age of Hidalgo State inhabitants is 25 years ( 24 for men, 26 for women), whereas in the case of Huazalingo the median age is 22 (men 20, women 23). In the case of the capital of the Hidalgo State, Pachucha, the median age is 28 . The numbers 
indicate the relatively high population growth and the high fertility rate. The annual population growth of the Huasteca Hidalguense in 1995-2005 was as high as $1.1 \%$. (Vázquez Sandrin 3 ). The fertility rates are particularly high among the Indian women. The fertility rate of nahuatl-speaking women in la Huasteca Hidalguense in 1995-1999 was approximately 4.1\%, i.e. higher by 0.4 than the average for the whole the La Huasteca Hidalguense region and higher by $1.3 \%$ comparing to the average for the whole Hidalgo State (Vázquez Sandrin 4).

The author of this article has carried out the field research in the Huazalingo Municipality since December 1999 till the present, collaborating with the Centro de Investigaciones y Estudios Superiores en Antropologia Social (CIESAS). The principal research method is based on the participant observation and the extended case study, which involves a comparison of the results of the empirical research with the source literature. The author's main place of residence during the investigation was the community of San Juan and most of the data was collected in that community. San Juan is located at the distance of around 2 kilometres from the municipal seat, Huazalingo; the road leading to Huzalingo divides the community of San Juan in two not equal parts. In 2010, the total population of San Juan was 454 inhabitants.

Since the Conquest, the diet of Mesoamerican Indians was based on local products obtained through plant cultivation, livestock farming, hunting and gathering, and the surplus was sold or traded for other agricultural products in order to diversify their diet or to buy household utensils. Notwithstanding, nowadays, the agricultural production cannot provide sufficient surplus for living expenses, or offer the financial means to buy industrial products. Therefore, the peasants are looking for the optional livelihood strategies. The focal point of all of their activities is corn as the core element of their rituality, cosmology and the religious life. At the same time, corn represents the staple food crop and the major source of calories. Corn constitutes half of the total amount of food consumed every year and it provides almost half of the calorie requirements. The main dish, tortilla, provides half of the calories and one third of proteins consumed by the inhabitants of Mexico. These figures are much higher in the rural sector, i.e. $65 \%$ of calories and between 50 and $70 \%$ of proteins (Massieu-Trigo 283-284). Corn represents also the main component of the daily and festive dishes and it is an essential ingredient of religious and healing ceremonies. During recent years, there has been an increase in consumption of meat and processed food, refined sugar, sugared soft drinks, biscuits, candies, etc. The higher calorie intake and the increase in consumption of the processed food have had a major influence on the devastating twin epidemics of obesity and diabetes. 
The inhabitants of the villages of the municipality practise subsistence agriculture. The increasingly poor agricultural product price to industrial products price ratio, the difficult access to the market, to credits and bank accounts, an excessive number of people comparing to the cultivable land (in San Juan, Huazalingo the maximum plot is 4 ha, although a number of landless peasants called avecindados is growing very quickly) - make it impossible for the peasants to maintain their families on the basis of the agricultural activity, however paradoxically it might sound. As mentioned above, the prices-scissor of agricultural products and economic crisis in the agriculture sector, observed in Mexico since 1990's, forced the Indian peasants to diversify their income and their search for alternative complementary strategies (Tiedje 265; Piotrowska 117-502). Their decisions, although conscious and deliberate, are constrained by the options that are available to them, given the overall context and the conditions in which they operate. Many of them find work as bakers, craftsmen, carpenters, ambulant vendors or traditional healers (curanderos). Although migrations represent only one of the many optional solutions and social-economic strategies carried out by the Indian peasants in order to balance the family budget, in the $20^{\text {th }}$ century it became a preferred option for solving the acute problems faced by them. ${ }^{1}$ On the other hand, such actions are facilitated thanks to the improvement of transport conditions, technological development (the media, radio, internet), allowing for an increased range and duration of migrations. Young people migrate from their communities in search of employment ${ }^{2}$ and the migration constitutes the major source of income for their families. Summing up, we can say that the la Huasteca Hidaguense region and San Juan village live on the residents' migration.

The first waves of migrations in the La Huasteca Hidalguense region started since the mid- $20^{\text {th }}$ century. Since the 1980 s till the beginning of the $21^{\text {st }}$ century the main centre attracting migrants from the rural areas was the capital, Mexico City. Other important directions of migration from the region are Pachuca (capital of Hidalgo state), Tampico, Guadalajara and, in the last few years, Monterrey. Currently, the most important form of economic migrations is connected with a seasonal work (generally lasting several

\footnotetext{
${ }^{1}$ The results of the populations census confirm the high mobility and migration rates of Mexican Indians. According to the census of 2000, more than one million of Indians were born in different federative entity than one where they were registered in the census (García et al. 67).

${ }^{2}$ The first migrations in the $20^{\text {th }}$ century were directly related to the issues of the land ownership and the struggle over land (lucha por la tierra). Some Indian peasants escaped from the persecutions of big landowners, others tried to obtain financial resources for future investments in land freshly recovered from them (Vázquez-Flores, and Hernández Casillas 73).
} 
months) in the modern farms located in the north-eastern part of Mexico (the Indian peasants are hired for cattle breading, fruits, vegetables and flowerspicking, etc.) especially in the farms producing for the export market (Sánchez-Saldañ 2).

When describing the situation of poverty, the following factors are usually analysed: location, geographic zone, remoteness or proximity to big urban centres, ethnic origin and gender. The poverty rate and the marginalisation of the Indian communities are substantially higher than in the non-Indian communities, when taking into account income, access to goods and services, health, education, employment and decision-making power. Although men and women share the same conditions of poverty, women are much more affected by this situation. Women head the majority of single-parent households and have to face the lack of work and access to productive resources. It is generally recognised that the Indian women are doubly or even triply discriminated, because they are Indians, because they are poor and because they are women (Tiedje 268). The situation of Indian women is extremely difficult because they have to face various levels of discrimination and gender-based violence. In the 1980s, some feminists from developing countries started to analyse the phenomenon of poverty from a gender perspective, and they identified a series of conditions that affected the situation of women. At the same time, they emphasised that the number of poor women was much higher than men, the poverty of women was more extreme, and that increasing women's poverty was a noticeable trend. In order to summarise the whole set of phenomena they used a term feminization of poverty (CEPAL. Entender la Pobreza 13). ${ }^{3}$ It is obvious that the background for poverty, violence and discrimination experienced by women is multi-factorial and it constitutes a by-product of a warped hierarchical society that due to the vicissitudes of history favoured men over women and Europeans over Indians (Herrera and Duhaime). However, taking into account a growing number of women active in the labour market and being the heads of households, the exacerbation of women's poverty provokes a slowdown in the local and global economic growth (Buvinic).

The traditional Indian communities tend to maintain conservative standards with regard to the traditional gender roles. The women carry out their daily activities in the specific spaces determined by custom and legitimised by standards (Alcalá 142). It is commonly agreed that Indian women in rural communities are confined to the domestic domain, while the public or political sphere is dominated by men. The term "domestication of

\footnotetext{
${ }^{3}$ The term "feminization of poverty" is attributed to Diana Pearce.
} 
women" that served as a title of an important study of Barbara Rogers (2226) perfectly describes the condition of discrimination against women and their confinement to the domestic sphere. The Indian women, trapped in the kitchen and in their traditional gender roles, were considered to be the nurturers of the family and they did not have to have contact with people outside their native community. The traditional division of labour by gender implied sharp distinctions between the masculine and feminine roles, and it was particularly visible in the case of the agricultural division of labour.

Nahua women in the Huazalingo Municipality generally do not have to engage in the agricultural activities. Notwithstanding, within the local food system, they have to comply with the rules that assign them certain duties depending on their age. As a rule, men have to participate in the majority of the agricultural activities, for example, those related to sowing and animal breeding, i.e. the first stage of the food system, the production of food, whereas, women first of all prepare meals, i.e. they are active in the final stage of the food system. The additional work necessary for the daily cooking tasks, for example, fetching water and wood, should be done by both men and by women as needed. Ever so, during the large festivities, the participation of all the family is required; women with girls prepare meals and men with boys make flower arrangements and decorations (flower necklaces, arches decorated with yellow and orange marigolds called in nahuatl cempoalxóachitl).

Preparing meals and washing clothes are two main activities of women that consume the majority of their daily routine and they represent a real challenge in a region having a changing climate. The clothes get dirty very quickly because of humidity, and in the rainy season, they dry much slower than in other climate. Women also play a very significant role in the upbringing of children. They have to carry hot lunches for their children in the primary school and kindergarten, participate in parent-teacher-meetings, help children with their homework, sew clothes and prepare decorations needed for school celebrations. Simultaneously, they are obliged to clean the school buildings periodically in accordance with the schedule (the schools in Indian villages do not employ professional cleaners and all the cleaning work is performed by the mothers).

Time represents probably the only resource that the poor people have at their disposal in an abundance. Nevertheless, many studies have demonstrated that in poor families the average man has at his disposal more leisure time than the average woman (Buvinic). Edward T. Hall included the traditional Latin-American cultures in the group of the societies that he called polychronic cultures. The specificity of such cultures is based on doing multiple things at a time, whereas the modern societies, as the typical 
representatives of monochronic cultures prefer scheduling, planning and doing one thing at a time (Hall). This definition is even more true in case of women. Indian women take children with them when leaving house to assist meetings, or carry firewood, and, in the meantime, they are breastfeeding, embroidering napkins or just gossiping. Nevertheless, the status of women as well as their roles in the family and in the public sphere are constantly changing over time. Many scholars and government agencies report a gradual increase in women's status and the improved access of women to education, health care and management positions among the traditional indigenous groups of Latin American and Asian countries (Binh 136).

According to the traditional cosmology of the Nahua Indians, the secret of women's fertility carries a symbolic meaning and it is related with the cult of Earth and with agricultural rituals. Motherhood possesses an enormous importance for the indigenous communities and it seems to be perceived as a destiny of woman. Generally, indigenous women have more children, comparing with the average national rate. Notwithstanding, when analysing the past decades, there is a considerable decline in the birth rate. Currently, women utilise various birth control methods, however, in spite of the state policies and programs of the birth control, there are still many teen mothers. The families are patrilineal and patrilocal i.e. women leave their houses to live with their husbands, yet there are many female-headed households that are more vulnerable and poor when comparing with others. It is also the case of young women who escaped from their husbands because of intra-family violence. Peasant women rarely ask their husbands to pay for the child support. There are no divorces, few marriages but a lot of unofficial separations. In some villages, several men have two unofficial wives, frequently sisters. It is the case of San Francisco village that is "famous" for having many families, consisting of two women and one man. Just 40-50 years ago, parents chose a husband for a girl, and the majority of women married very young, being 15 or even 13 years old. Currently, young people choose their partners in an independent manner, frequently, while working as temporary farm labourers, notwithstanding, there are only few legalised marriages.

The most important "revolution" that enabled to cut the time that the Indian women had to spend in the kitchen with no doubts dealt with the preparation of meals on the basis of the most important cereal in Mesoamerica, i.e. corn. Traditionally women "reign" in the kitchen and they have to spend much of their time preparing meals. Up to the early 1970s, women had to get up very early to perform all the procedures related to the transforming of nixtamal (tortilla dough) into tortilla. The introduction of manual nixtamal mills, tortilleras (tortilla presses made of wood or metal), 
and, then, electric nixtamal mills, revolutionised all the process of preparing of the sacred and most important meal (tortilla) and saved women's time and work, although some of elderly men were not eager to accept the modern techniques. Other inventions that have improved the lives of women, or at least, saved their time are blenders (it means that women do not need metate grinding table to grind chili pepper, cacao, etc., that is very hard and timeconsuming work), and refrigerators (they can prepare dough for two or more days and store it in a refrigerator). The next stage of the development of the tortilla preparation is tortilleria (tortilla bakery). Currently, in San Juan a group consisting of 5 women operates one electric nixtamal mill and other women have to pay a small fee for milling corn dough there. The majority of women do not have manual mills yet, therefore, once, when suddenly power went out in San Juan, it caused a great deal of confusion. The same group of women operates also the tortilleria bakery that they put into operation only in case of big orders because they do not wish to dirty the machinery while producing a small amount of tortillas. In spite of the important revolutionary changes in the food-preparation processes, the rural women have to dedicate almost twice as much time to prepare meals as women living in urban centres (Pederzini 37).

Although till 2017 women were not allowed to participate in the cargo system (sistema de cargos, i.e. a system of local authorities, constituting a hierarchy of secular and religious posts held by the members of Indian villages in the form of unpaid responsibility), they have to fulfil some of the duties of their relatives in their absence in the village. Due to temporary migrations of young males, their female relatives (mothers, sisters or wives) are obliged to replace them and perform their duties related to the cargo system, i.e. participate in the meetings of community members, play the roles of mayordomos (organisers of patronal festivals), perform faenas (communal work obligations), pay contributions to the village authorities, etc. In San Juan, the only cargo of mayordoma, i.e. a female organiser of the patronal feast, was the mayordoma of the feast of the Immaculate Conception (one of the three patron saint festivals in San Juan). ${ }^{4}$

A constant increase in the number of working women in the rural regions of Mexico that started in 1980s, was paralleled by the crisis in the rural economy. During the decade of 1970s, the majority of the Mexican peasants experienced increasing difficulties to earn their living from agriculture. They had to diversify their economic activities and find new livelihood strategies.

\footnotetext{
${ }^{4}$ In 2018 , for the first time in San Juan, a woman was elected to the position of mayordoma of the feast of Santiago. In in 2017 and 2018, two women were assigned tasks within the framework of the cargo system, although they do play auxiliary roles only.
} 
It is not individual but collective, common effort and the decisions are made by the whole domestic groups because the results of the changing of traditional gender roles resulting from migrations affect all family members (Klein and Vázquez-Flores 30). While some family members stay home to work the land and fulfil the duties related to the cargo system, others leave to find jobs as day labourers, industry workers or merchants, or migrate to urban centres.

With no doubt, the importance of financial resources provided by women for a family budget has grown significantly (in consequence of price scissors in agriculture, the agricultural activity has to be complemented by the resources coming from other economic sectors, for example, door-to-door selling, artisan work, and work as traditional healers). Notwithstanding, it is relatively difficult to assess the share of women's earning contribution to the family budgets on the ground that the estimates of women's work appear to be on the low side. Whenever they perform work for the community (village) or the family, the work of women is often defined using a disparaging term "help" (García et al. 35). The main problem they have to affront is the necessity to combine two goals - productive and reproductive, because they are very much involved in the process of bringing up children. It means that they have to take jobs that allow them to meet both these responsibilities. Such jobs generally may be found in the informal sector and, therefore, they are poorly paid.

Trade, especially door-to-door trade, represents the type of work preferred by women because it enables them to combine flexibly domestic chores, childcare and income generation, allowing them to adapt their sales times to the requirements of the domestic work and enable their children or grandchildren to accompany them. They have to carry goods on their shoulders, backs or heads like the merchants in the pre-Columbian era. They are the modern-day successors of the professional prehispanic merchants and travellers of Aztec Empire called pochtecas. Pochtecas represented a separate group of the long-distance traders that supplied Tenochitlan with luxury and exotic goods from distant regions.

In the process of the reorganisation of the local and regional economies, women have played a major part. The number of women that took up paid work or intensified the work that they had previously, increased substantially. Huazalingo, Doña Caritina Lara of San Juan, my hostess and friend, is the best example of a flexible and multitasking modern Indian woman. She works as curandera (traditional healer), itinerant vendor selling second-hand clothes, fruits, food products, she helps her husband in the farm work and she fulfils all the duties of an average Indian woman as a mother, grandmother and wife. When her husband got ill, she had to assume more tasks, because 
even the busiest of women are able to intensify their work when needed. Indian women are the specialists of a polychronic system of time and experts of the optional time usage.

Until the end of $20^{\text {th }}$ century, Indian women were almost invisible as scholars, state authorities, and politicians. Their participation in the political life was very limited. As the elderly inhabitants of San Juan remember it today, during the period of the so called lucha por la tierra (struggle over land), i.e. violent and bloody Indian peasants movement that started in 1970s, women generally did not participate actively in the events. They were assigned secondary duties of preparing and serving meals for the combatants and performing other household chores. However, with time, the political participation of younger generation of women has increased. They take an active part in the local electoral campaign before the elections of a president of municipality. Therefore, political leaders and candidates seek their help and assistance. Notwithstanding, as many women complain, after the elections they play a secondary role only because the key positions are still reserved for men.

Considering the above, the local and state authorities and nongovernmental organisations started to offer more and more programs designed especially for women, enabling them to become vocationally active. However the majority of these programs are short-lived and they fail quickly upon completing the initial phase. The instructors of the organisations promote and discuss with women some psychological and family related issues, for example, intra-familiar violence, trying to develop their selfesteem. The younger generation of women is capable to defend themselves and they demonstrate their independence and self-respect. This assumption may be confirmed by one incident that occurred during the meeting of comuneros (members of agrarian community) in San Juan when a group of young women participating in the assembly filling in for their absent husbands, commented with laughter "We are worth as much as men." Other organisations and agencies offer special trainings to promote the changes in eating habits, for example, trying to persuade women to utilise new sources of proteins (soya) or to consume more vegetables. The DIF (Sistema Nacional para el Desarrollo Integral de la Familia) instructor visited San Juan many times to teach women how to prepare new meals, for example, orange jams, soya meals, etc. Women patiently participated in the training, sometimes even with enthusiasm, however, I have never seen any family that so far have utilised new recipes in their homes afterwards.

Although the division of labour by gender seems very strict, in the practice, it may be flexible. Because of the high rate of the labour migration among young men, the division of labour by gender is modified. There is a 
rule applicable to the Mexican rural areas and to other developing countries that the poorer a family is, the more important women's participation in the agricultural work is (Rogers 165). Unfortunately, it means that women have to take on more tasks now than in the past, because men almost never take over women's work in the kitchen or other domestic chores.

A strict gender division of labour implies also the existence of many prohibitions, orders and taboos. The example of the taboo that has survived the waves of modernity is a prohibition for women to ring the bells. In the villages of the Huazalingo Municipality, women are not allowed to ring a bell, and it is believed that otherwise a bell could break. At the same time, women have to fight discriminatory prejudice, superstitions and criticism from the neighbours that support more traditional family models. For example, curanderas and itinerant vendors who have to travel outside their home village, are gossiped to have lovers in other villages.

Traditionally young men are more inclined to migrate than women. Men are more mobile whereas women cannot leave and liberate themselves from the oppressive situation as readily as men do (it is harder for them to find a paid employment, they exhibit much closer ties to their families and children). Migrant women from the Indian villages can obtain worse paid jobs than men, hence, they usually find employment in the cities as domestic workers (the demand for domestic workers in the cities is very high although the salaries are low), or as small shop assistants (Informe sobre Desarrollo Humano 59). They start to migrate from the age of twelve-thirteen and the maximum rate of migration is registered between 15 and 29 years of age. After getting married, women less frequently leave their home village. The owners of modern farms that employ seasonal workers take hold of the opportunity to employ female workers and whole families. Some of them hire babysitters to take care of children when their mother works in the field. Due to the increasing feminisation rate of migrations to modern farms and more contacts between young people of different sexes, the growing number of young women move to other villages as wives of men whom they have come to know during work (the families generally have patrilocal character).

The older generation expresses their general concern and uncertainty about the behaviour and attitudes of younger men and women. The analysis of their attitudes seems to be important because the effects of globalisation tend to have a generational character. The younger generation is responsible for the majority of migrations in the second part of $20^{\text {th }}$ century and the beginning of $21^{\text {st }}$ century on the local, regional and country level, even on the international level, hence, they form the so called migratory culture. However it should be stressed that a new and very dangerous phenomenon has emerged in la Huasteca Hidalguense: a substantial reduction in the number of 
young men aged 15 to 29 . Around $82 \%$ of people emigrating to the United States are men and $18 \%$ are women, with half of all emigrants in the 15 to 29 years group (Serrano-Avilés 65). The intensification of migration of young generation entails a significant risk of the loss of the human capital, because it is on them that the Indian communities place hopes to fight underdevelopment and find new, creative solutions to emerging economic and social problems.

The ongoing changes in women's status and in living conditions in the Mexican Indian villages have weighed increasingly on the local economy. Current economic and political changes within the framework of the phenomenon called globalisation have brought Indian women new opportunities and new challenges. However, the changes in women's status do not necessary mean the improvement of their living conditions. Frequently, it means that women have to take even more tasks and responsibilities while they are not freed from the old ones. It implies an increase in terms of the burden of extra workload.

Nonetheless, the wind of change has eradicated some taboos related to women. For example, in the past women did not participate in the Day of the Dead ceremonies (xantolo) as dancers. Nowadays schools and kindergartens promote participation of women, i.e. mothers of pupils and schoolgirls, in the ritual dances, although elder people criticise such ,innovations.” Irrespective of the direction and the rate of changes, traditional healers (curanderas), constitute a group of women that are always on the forefront of modernity and development. They are not only doctors who cure human body, shamans or magicians, but also philosophers, thinkers who constantly seek to understand the rules, norms and principles that govern the world. It is the most active and open-minded group of Indian women and their curiosity about the world, flexibility and the support for the idea of the life-long learning give some hope for the future of the traditional Indian societies and the future status of women. Curanderas are the best example of how to combine respect for old traditions, maintaining collective memory and identity with an attitude open to change, readiness to learn new skills and absorb new ideas. It is worth conducting a detailed research in the future in order to determine precisely the role of this specific group of Indian women in the context of the increasingly globalised world. 


\section{Works Cited}

Alcalá, Graciela. "Las Prácticas de la Mujer en la Definición de Una Región." Huasteca II. Prácticas Agrícolas y Medicina Tradicional. Arte y Sociedad, edited by Graciela Alcalá and Jesú Ruvalcaba. CIESAS, 1993, pp. 141-47.

Anuario Estadístico y Geográfico de Hidalgo 2013. INEGI/ Gobierno del Estado de Hidalgo, 2014.

Binh, Nguyen Thanh. "The Changes of Women's Position: The Vietnam Case." International Journal of Innovative Interdisciplinary Research, vol. 1, 2011, pp. 126-138.

Buvinic, Mayra. Mujeres en la Pobreza: Un Problema Global. BID, 1998. http://www20.iadb.org/intal/catalogo/PE/2010/07153.pdf. Accessed 14 Jan. 2017.

Censo de Población y Vivienda 2010. INEGI. http://www.inegi.org.mx/ eventos/2013/desigualdades/doc/P-RosamariaRuvalcaba.pdf. Accessed 16 Jan. 2017.

CEPAL. Entender la Pobreza Desde la Perspectiva de Género. CEPALUNIFEM, 2004. http://repositorio.cepal.org/bitstream/handle/11362/5918/ S0400008_es.pdf;jsessionid=E4FD108C0B5A0DB591E98ECEA0AFD0 0E? sequence $=1$. Accessed 27 Jan. 2017.

García, Luz María, et al. Las Mujeres Indígenas de México: su Contexto Socioeconómico, demográfico y de Salud. INMUJERES, 2006.

Hall, Edward T. The Dance of Life: The Other Dimension of Time. Doubleday, 1983.

Herrera, Carmen and Bernard Duhaime. "La Pobreza de las Mujeres Indígenas en México. Una Intersección de Discriminaciones en las Políticas de Estado." Debate Feminista 49, 2014, pp. 263-285. http://www.sciencedirect.com/science/article/pii/S0188947816300160. Accessed 8 Feb. 2017.

Informe sobre Desarrollo Humano de los Pueblos Indígenas de México. El reto de la desigualdad de oportunidades. CDI-PNUD, 2010. http://hdr.undp.org/sites/default/files/mexico_nhdr_2010.pdf. Accessed 7 Jan. 2017.

Klein, Alejandro, and Erika Vázquez-Flores. "Los Roles de Género de Algunas Mujeres Indígenas Mexicanas desde los Procesos Migratorios y Generacionales." Journal of Behavior, Health \& Social Issues, vol. 5, no. 1, 2013, pp. 25-39. http://www.journals.unam.mx/index.php/jbhsi/ article/view/38611/pdf1. Accessed 05 Feb. 2017. 
Massieu-Trigo, Jolanda, and Jesú Lechuga Montenegro. "El Maíz en México: Biodiversidad y Cambios en el Consumo.” Análisis Económico, vol. XVII. 36, 2002, pp. 281-303. http://www.redalyc.org/service/redalyc/ downloadPdf/413/41303610/El+ma\%EDz+en+M\%E9xico:+biodiversida $\mathrm{d}+\mathrm{y}++$ cambios + en $+\mathrm{el}+$ consumo/1. Accessed 06 Feb. 2017.

Medición de Pobreza Municipal 2010. Mexico: Coneval, 2011. http://www.coneval.org.mx/Medicion/Paginas/Informacion-por-

Municipio. Accessed. 7 Jan. 2017.

Panorama Sociodemográfico de Hidalgo. Indicadores e Información sobre los Pueblos Indigenas de Hidalgo. CDI-PNUD, 2010. http://www.cdi. gob.mx/pnud/memoria_taller_indicadores_hidalgo_2009. pdf. Accessed. 7 Jan. 2017.

Pederzini-Villareal, Carla. "La Cocina: ¿Destino o Privilegio Femenino?" Pan, Hambre y Trascendencia: Diálogo Interdisciplinario sobre la Construcción Simbólica del Comer, edited by Carlos Mendoza Álvarez and Ángel Francisco Méndez Montoya. Universidad Iberoamericana, 2009, pp. 29-57.

Piotrowska, Zofia. "Cambios de Fuentes de Ingreso y Métodos de Generarlo entre los Habitantes de la Comunidad de San Juan Chalchocotla (Municipio de Huazalingo), en la Huasteca Hidalguense." Actas Latinoamericanas de Varsovia, vol. 25, 2002, pp. 117-150.

Rogers, Barbara. The Domestication of Women: Discrimination in Developing Societies. Routledge, 1989.

Sánchez-Saldaña, Kim. "Acerca de Enganchadores, Cabos, Capitanes y Otros Agentes de Intermediación Laboral en la Agricultura." Estudios Agrarios. Revista de la Procuraduría Agraria, vol. 17, 2001, pp. 61-103.

Serrano-Avilés, Tomás. Migración Internacional y Pobreza en el Estado de Hidalgo. UAEH, 2006.

Tiedje, Kristina. "Gender And Ethnic Identity In Rural Grassroots Development: An Outlook From The Huasteca Potosina, Mexico." Urban Anthropology, vol. 31, no. 3/4, 2002, pp. 261-316.

Vázquez-Flores, Erika Julieta, and Horacio Hernández Casillas. Migración, Resistencia y Recreación Cultural. INAH, 2004.

Vázquez-Sandrin, Germán. "Dinámica Demográfica y Política de Población. El Caso de las Regiones Indígenas del Estado de Hidalgo." Paper, $X$ Reunión Nacional de Investigación Demográfica en México. Escenarios Demográficos y Política de Población en el Siglo XXI. 2010. http://www.somede.org/images/x-reunion.pdf. Accessed. 17 Feb. 2017. 